УДК 582.594.2+581.9(597)

\title{
The genus Cypripedium (Orchidaceae) in the flora of Vietnam
}

\author{
L. V. Averyanov ${ }^{1}$, C. X. Canh ${ }^{2}$, N. H. Tuan ${ }^{3}$, V. A. Phu², K. S. Nguyen ${ }^{4}$, T. H. Nguyen², T. V. Maisak ${ }^{1}$ \\ ${ }^{1}$ Komarov Botanical Institute RAS, Prof. Popov St., 2, St. Petersburg, 197376, Russia.E-mail: av_leonid@mail.ru \\ ${ }^{2}$ Center for Plant Conservation, 25/32, lane 191, Lac Long Quan, Nghia Do, Cau Giay District, Ha Noi, Vietnam \\ E-mail: centerforplantconservation@gmail.com; cxcanh@gmail.com \\ ${ }^{3}$ Department of Pharmacognosy, Hanoi University of Pharmacy, 13-15, Le Thanh Tong St., Hoan Kiem district, Hanoi, Vietnam \\ E-mail: tuandl50@yahoo.com \\ ${ }^{4}$ Institute of Ecology and Biological Resources, Vietnam Academy of Science and Technology, 18 Hoang Quoc Viet, \\ Cau Giay, Ha Noi, Vietnam.E-mail:nskhang@gmail.com
}

Key words: Cypripedium, Vietnam, plant taxonomy, plant diversity, nature protection.

Summary. The genus Cypripedium includes 40-45 species distributed mainly in areas of Holarctic region with temperate climate. Its highest species diversity is observed in the eastern part of mainland Asia and in Northern America. In intact habitats, some species of this genus are quite common playing significant role in plant communities forming picturesque landscape aspects during anthesis. Some Cypripedium species are not uncommon in uplands and mountains of subtropical countries, but few of them reach tropical zone. In Central America these are Cypripedium irapeanum, C. molle and C. dickinsonianum distributed from Mexico to Guatemala, Salvador and Honduras. In Asia only two species - Cypripedium lentiginosum and C. subtropicum, reported in the paper, reach truly tropical zone. Localities of these species recently discovered in northern Vietnam represent southernmost locations of the genus area in the Old World. A brief taxonomical review of two discovered species in the flora of Vietnam is presented in the paper. The treatment includes key for species identification; standard taxonomic citations for the genus, sections, species and synonyms; data on types and their locations; available information on ecology, phenology and distribution, expected IUCN Red List status; notes on phylogeny, taxonomy, geography and possible conservation actions, as well as the list of studied specimens and relevant materials.

\section{Род Cypripedium (Orchidaceae) во флоре Вьетнама}

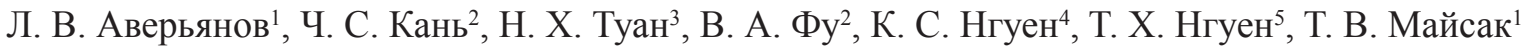 \\ ${ }^{1}$ Ботанический институт им. В. Л. Комарова РАН, ул. Проф. Попова, д. 2, Санкт-Петербург, 197376, Россия \\ ${ }^{2}$ Центр охраны растений, 25/32, линия 191, Лак Лонг Куан, Ни До, район Кай Зяу, Ханой, Вьетнам \\ 3Отдел фармакогнозии, Университет Фармации г. Ханоя, 13-15, ул. Ле Чан Тонг, район Хонг Кием, Ханой, Вьетнам \\ ${ }^{4}$ Институт Экологии и Биологических ресурсов, ВАНТ, 18 ул. Хоанг Куок Вьет, район Кай Зяу, Ханой, Вьетнам
}

Ключевые слова: Cурripedium, Вьетнам, таксономия растений, разнообразие растений, охрана природы.

Аннотация. Род Cypripedium объединяет 40-45 видов, распространенных главным образом в областях Голарктического царства с умеренным и теплоумеренным климатом. Его наибольшее видовое разнообразие наблюдается на востоке континентальной Азии и в Северной Америке. В ненарушенных местах обитания некоторые виды рода довольно обычны, играя заметную роль в сложении растительных сообществ и формируя во время цветения колоритные ландшафтные аспекты. Некоторые виды рода Cypripedium нередки на 
плоскогорьях и в горных местностях ряда субтропических стран, но лишь очень немногие заходят в зону тропиков. В Центральной Америке это такие виды, как Cypripedium irapeanum, C. molle и C. dickinsonianum, pacпространенные в Мексике и южнее до Гватемалы, Сальвадора и Гондураса. В то же время в Азии только два вида - Cypripedium lentiginosum и C. subtropicum, приводимые в статье, достигают истинно тропической зоны. Местонахождения этих видов, недавно обнаруженные в северном Вьетнаме, представляют самые южные точки ареала рода в Старом Свете. В статье представлен краткий таксономический обзор двух вновь найденных видов рода во флоре Вьетнама. Он включает ключ для определения видов; стандартное таксономическое цитирование для рода, секций и видов; сведенную синонимику; данные о типах и местах их хранения; всю имеющуюся информацию по экологии, фенологии и распространению приводимых таксонов, предполагаемый охранный статус видов в категориях Международного союза охраны природы (IUCN Red List); заметки о филогении, таксономии, географии и рекомендуемых мерах охраны, а также список изученных образцов.

The genus Cypripedium L. includes 40-45 species distributed mainly in areas of Holarctic region with temperate climate. Its highest species diversity is observed in the eastern part of mainland Asia and in Northern America. In their intact habitats, some species of the genus are quite common playing significant role in plant communities forming picturesque landscape aspects during anthesis (Averyanov, 1999, 2000). Some Cypripedium species are not uncommon in uplands and mountains of subtropical countries, but few of them reach tropical zone. In Central America these species are Cypripedium irapeanum La Llave et Lex., C. molle Lindl. and $C$. dickinsonianum Hagsater distributed from Mexico to Guatemala, Salvador and Honduras (Cribb, 1997; Eccarius, 2009). In Asia only two species - Cypripedium lentiginosum P. J. Cribb et S. C. Chen and C. subtropicum S. C. Chen et K. Y. Lang, reported in this paper, reach truly tropical zone. Localities of these species recently discovered in northern Vietnam represent southernmost locations of the genus area in the Old World.

A brief taxonomical review of two discovered species in the flora of Vietnam is presented below. This treatment includes key for species identification; standard taxonomic citations for the genus, sections, species and synonyms; data on types; available information on ecology, phenology and distribution, expected IUCN Red List status; notes on phylogeny, taxonomy, geography and possible conservation actions, as well as list of studied specimens and relevant materials.

\section{The genus Cypripedium in the flora of Vietnam}

Cypripedium L., 1753, Sp. Pl.: 951; Cribb, 1997, Gen. Cypripedium: 1-301; Eccarius, 2009, Orchideengattung Cypripedium: 1-384.

Type: C. calceolus $\mathrm{L}$.

40-45 species. Europe, temperate and subtropical Asia (except arid areas), Himalayas, China, northern
Indochina, North and Central America (south to Honduras and Guatemala). In Vietnam two species.

\section{Key to species}

1. Stem to $1.2 \mathrm{~m}$ tall with many distant, uniform green leaves; flowers (1)2-7(14) in loose raceme to $25 \mathrm{~cm}$ long; lip yellow with brown or chestnut spots; staminode as large or little larger than filaments ....

C. subtropicum (C. sect. Subtropica)

- Stem less than $3 \mathrm{~cm}$ tall with 2 sub-opposite green leaves with many dirty violet spots; flower 1 on short peduncle; lip white to light yellowish with many purple-brown spots; staminode much longer and broader than filaments

C. lentiginosum (C. sect. Trigonopedia)

C. sect. Subtropica S. C. Chen et K. Y. Lang, 1986, Acta Phytotax. Sin. 24, 4: 317; Cribb, 1997, Gen. Cypripedium: 116; Eccarius, 2009, Orchideengattung Cypripedium: 338.

Type: C. subtropicum S. C. Chen et K. Y. Lang.

2 species (C. subtropicum S. C. Chen et K. Y. Lang, C. wardii Rolfe). Southern China (Tibet, S Yunnan), northwestern Vietnam. In Vietnam one species.

C. subtropicum S. C. Chen et K. Y. Lang, 1986, Acta Phytotax. Sin. 24, 4: 317, fig. 1; Cribb, 1997 , Gen. Cypripedium: 118; Chen, Cribb, 2005, Fl. China 25: 24; Eccarius, 2009, Orchideengattung Cypripedium: 339; Xu Zhihui, Ye Deping, 2010, Wild Orch. Yunnan: 37, fig. 016a, b. Fig. 1, 2.

Described from southwestern China. Type ("Xizang (Tibet), Medong, Hajin, alt. $1400 \mathrm{~m}$, in alder (Anus) forest, flowers yellow tinged with redbrown spots, 19 July 1980, B. C. Li et al. 11188") PE [PE 00027327] (holotype), [PE 00027328; PE 00027329] (isotypes).

$=$ C. singchii Z. J. Liu et L. J. Chen, 2009, Journ. Fairylake Bot. Gard. 27, 1: 1, fig. 1, 2. 
Described from southwest China. Type ("S Yunnan, on shrubby slope, alt. 1300 m, 20 June 2009, Z. J. Liu 4590") - NOCC (holotype).

Habitat, phenology and conservation status. Terrestrial rhizomatous herb. Primary and secondary broad-leaved evergreen and semideciduous forests (commonly with Alnus nepalensis D. Don) on steep slopes composed with soft shaly limestone, often along rocky stream valleys on moist alluvial well drained thin soils rich in humus. Fig. 1. (1000)1400$1600 \mathrm{~m}$ a. s. 1. Fl. July-August. Very rare. Estimated IUCN Red List status - EN.

Distribution. Southwestern and southern China: southeastern Tibet (Medong county) and southeastern Yunnan (Malipo county), northern
Vietnam: Ha Giang (Quan Ba district) and Lai Chau (Sin Ho district). Fig. 3A.

Notes. Distribution of this species is amazing for its striking disjunctions. The plant is known presently only in three miserable locations forming a triangle with arms approximately $1200 \times 1200 \times 300$ $\mathrm{km}$ (Fig. 3A). Though its formal area of occurrence is relatively large, the actual area of occupancy in fact is negligibly small. Additionally, all known populations are strongly depleted presently by commercial collecting and lose almost all mature, flowering size individuals. The last assessment estimates this species as Endangered [B2ab(ii,iii,v); C2a(i)] (Rankou, Averyanov, 2014b). However, plant certainly comes fast to full extinction due to
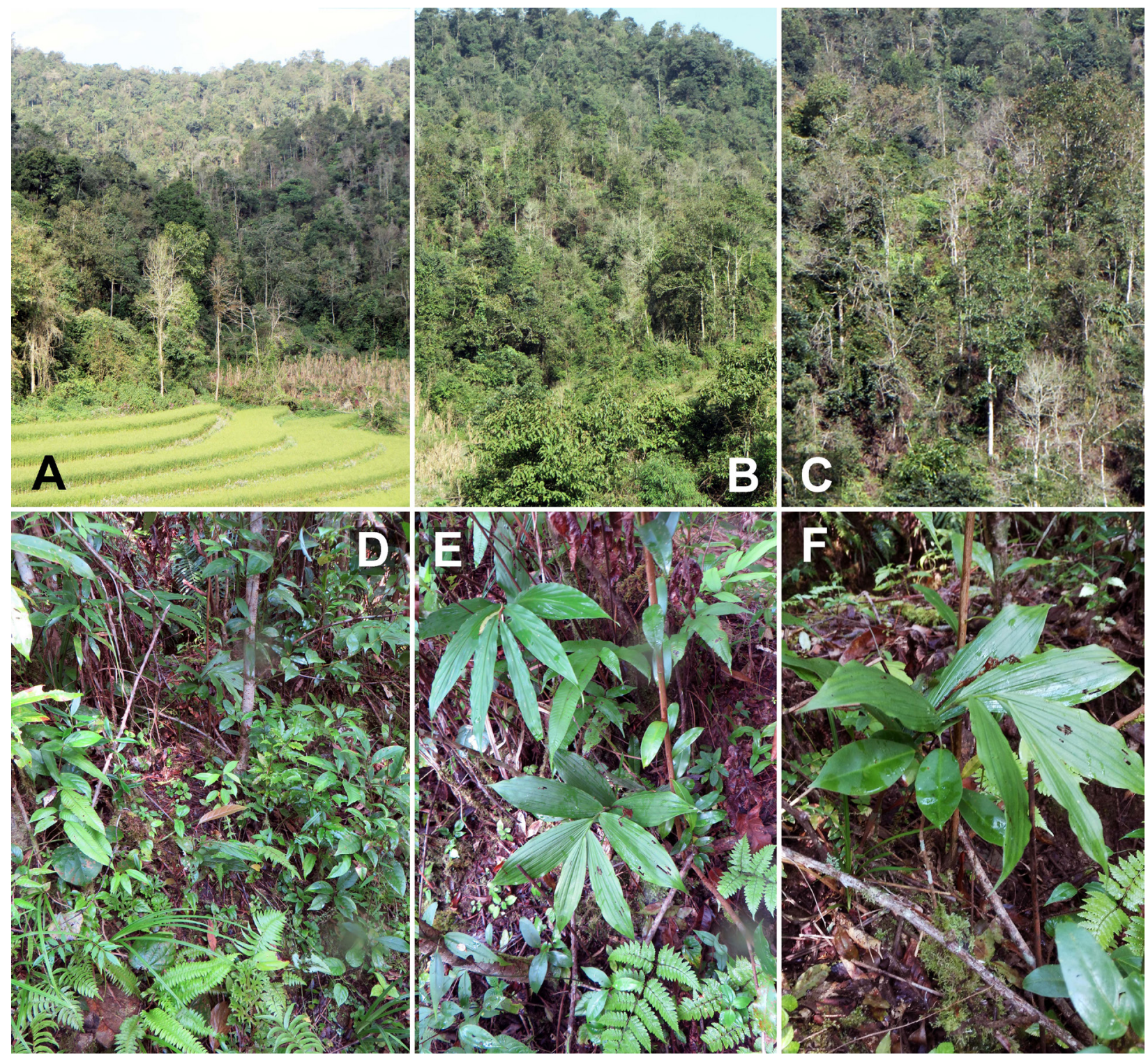

Fig. 1. A-C - Landscape and natural habitats of Cypripedium subtropicum in Lai Chau province of northwestern Vietnam. D-F - Plants of C. subtropicum in natural habitats in the same location (L. Averyanov et al., CPC 8243a). Photos of L. Averyanov and K. S. Nguyen. 


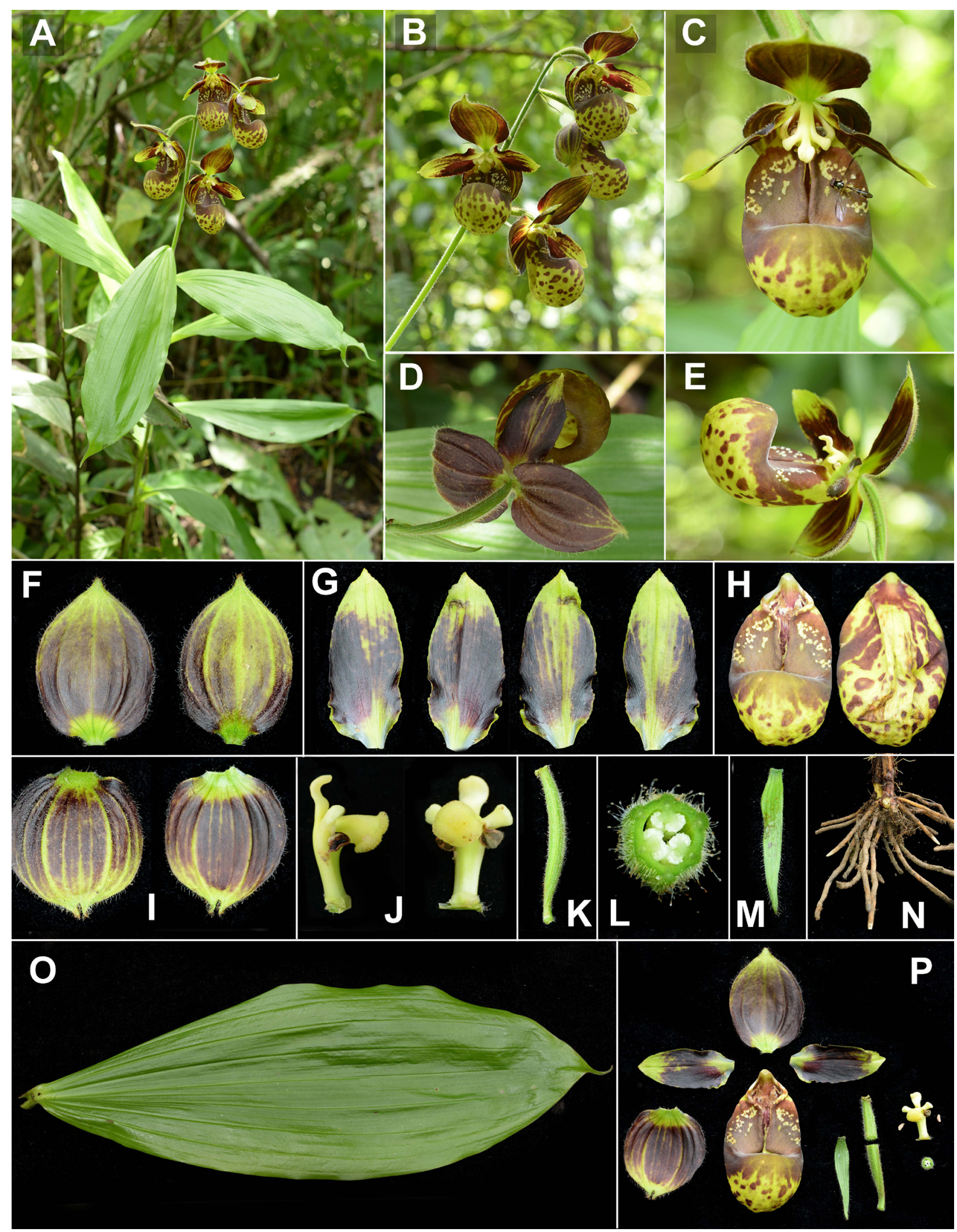

Fig. 2. Analytical photo-plate of Cypripedium subtropicum collected in Lai Chau province of northwestern Vietnam (2 August 2016, Chu Xuan Canh, s. n.). A, B - Inflorescence. C-E - Flower, frontal view, view from behind and side view. F - Median sepal, adaxial and abaxial surface. $\mathrm{G}$ - petals, adaxial and abaxial surface. H - Lip, frontal view and view from behind. I - Synsepal, adaxial and abaxial surface. J - Column, side view and view from below. K - Ovary, side view. L - Ovary, transversal section. $\mathrm{M}$ - Floral bract. $\mathrm{N}$ - Roots. $\mathrm{O}$ - Leaf, adaxial surface. P - Flattened floral parts. All photos and design of N. H. Tuan. 

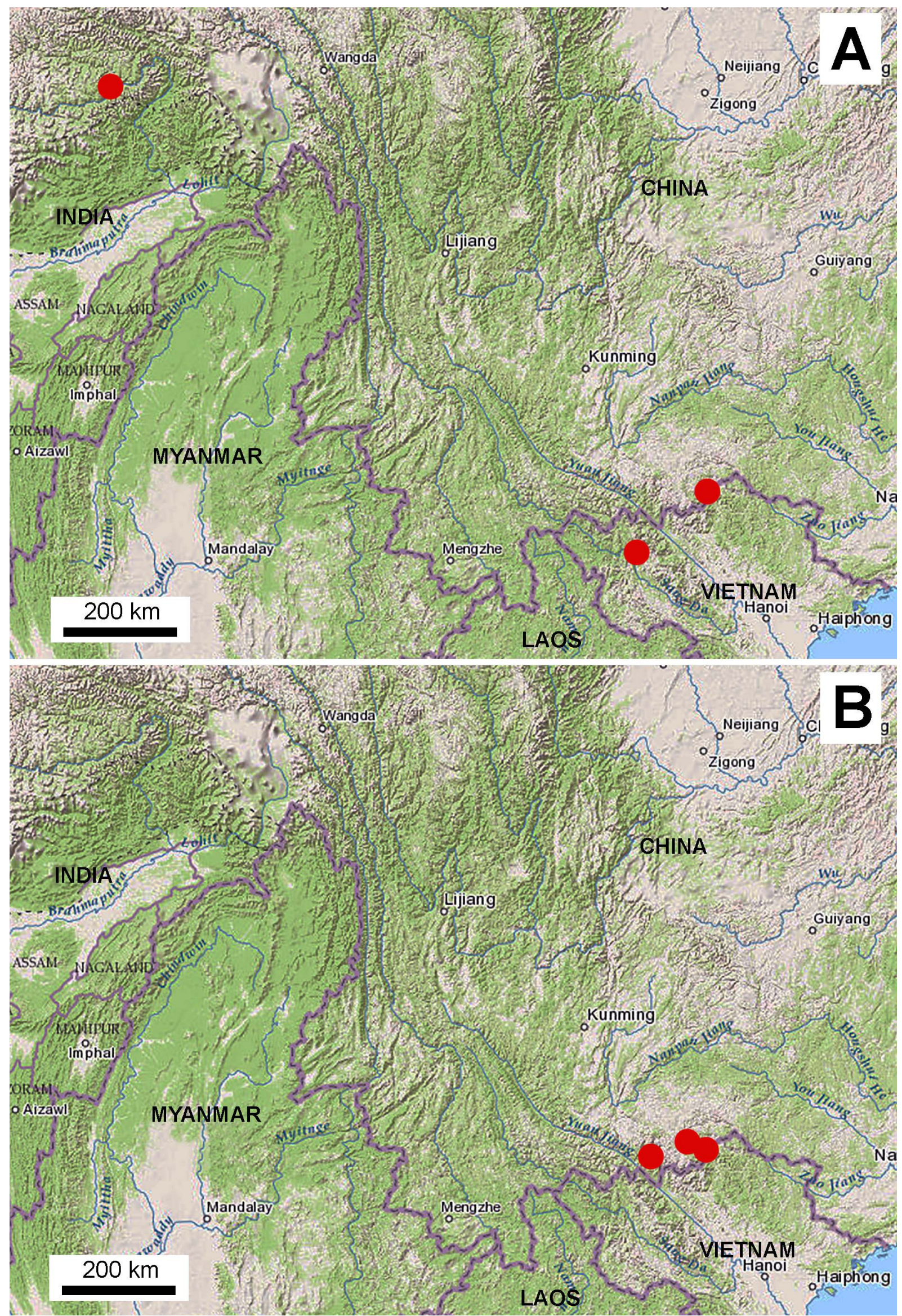

Fig. 3. Distribution of Cypripedium subtropicum (A) and C. lentiginosum (B). All presently known locations are designated by red rings. Design of L. Averyanov. 
overcollecting in all known locations. Additional field studies and botanical explorations in areas of the species occurrence may be recommended for discovery and effective protection of probably still existing new subpopulations.

The record of C. subtropicum in Sin Ho district of Lai Chau province of northwestern Vietnam presented here is new for the flora of the country. Early record in northern Vietnam in Ha Giang province is based on literature data (Jiang, Liu, 2009). Description of C. singchii (Liu, Chen, 2009) is based on material collected in the same place and probably from the same population (Jiang, Liu, 2009).

The general habit, many flowered inflorescence and small, filament-like staminode indicate very primitive character of this species, which is definitely much closer to Cypripedium ancestors than any other its congeners. It may be related solely to $C$. wardii Rolfe from eastern Tibet and western Yunnan. Both species form taxonomically very isolated group segregated in rank of separated section (Cribb, 1997; Eccarius, 2009) supported by molecular studies ( $\mathrm{Li}$ et al., 2011). Expected relations of this section to American Selenipedilum Pfitzer or Cypripedium irapeanum La Llave et Lex. (Chen, Lang, 1986) are based on superficial resemblance.

Studied specimen. Northwestern Vietnam, Lai Chau province, Sin Ho district, ..., 2 August 2016, Chu Xuan Canh, s.n. (Herbarium of Department of Pharmacognosy, Hanoi University of Pharmacy). Northwestern Vietnam, Lai Chau province, Sin Ho district, ..., August 2016, Chu Xuan Canh, s. n. (LE - photo). Northwestern Vietnam, Lai Chau province, Sin Ho district, ..., degraded primary and secondary evergreen broad-leaved forest on steep mountain slopes composed with shaly limestone at elevation about $1600 \mathrm{~m}$ a. s. 1., terrestrial herb to 1 $\mathrm{m}$ tall in wet shady place on forest understory, fruits greenish, very rare, 5 October 2016, L. Averyanov, N. T. Hiep, N. S. Khang, C. Q. Ngan, T. V. Maisak, CPC 8243a (LE - photo).

C. sect. Trigonopedia Franch., 1888, L'Orchidophile 8: 368; Cribb, 1997, Gen. Cypripedium:250; Eccarius, 2009, Orchideengattung Cypripedium: 260.

Type: Cypripedium margaritaceum Franch.

5 species (C. forrestii Franch., C. lentiginosum P. J. Cribb et S. C. Chen, C. lichiangense P. J. Cribb et S. C. Chen, C. margaritaceum Franch., C. sichuanense Perner). Northeastern Myanmar, south China (Yunnan, Sichuan, Hubei), northern Vietnam (Ha Giang). In Vietnam one species.
C. lentiginosum P. J. Cribb et S. C. Chen, 1999, Quart. Bull. Alpine Gard. Soc. Gr. Brit. 67, 2: 155; Chen, Cribb, 2005, Fl. China 25: 32. C. lichiangense S. C. Chen et P. J. Cribb subsp. lentiginosum (P. J. Cribb et S. C. Chen) Eccarius, 2009, Orchideengattung Cypripedium: 289.

Described from southern China. Lectotype ("S. E. Yunnan, mountains near Ma-li-po, 2100 m., May 1998, Li in Luo, s.n.") - K [K000364555], chosen by Eccarius (2009).

$=C$. lichiangense S. C. Chen et P. J. Cribb var. daweishanense S. C. Chen et Z. J. Liu, 2004, Acta Bot. Yunnan. 26, 4: 384. - C. daweishanense (S. C. Chen et Z. J. Liu) S. C. Chen et Z. J. Liu, 2005, J. Wuhan Bot. Res. 23, 3: 233.

Described from southern China. Type ("China, southeastern Yunnan, Pingbian County, Mt. Daweishan, alt. $2300 \mathrm{~m}$, in thickets, 28 May 2003, Z. J. Liu 26661") - Herbarium of Shenzhen City Wutongshan Nurseries (holotype).

$=$ C. malipoense S. C. Chen et Z. J. Liu, 2004, Acta Bot. Yunnan. 26: 382, fig. 1.

Described from southern China. Type ("China, southeastern Yunnan, Malipo County, Cizhuba, 2002, 06, 12, Z. J. Liu 2452") - Herbarium of Shenzhen City Wutongshan Nurseries (holotype).

Habitat, phenology and conservation status. Terrestrial and lithophytic rhizomatous herb. Primary and secondary broad-leaved evergreen open forests and thickets on rocky steep slopes and mossy boulders just below ridges composed with solid karstic limestone, commonly in grassy places on wet, well drained soils rich in humus. 2100-2300 $\mathrm{m}$ a. s. 1. Fl. May-June. Very rare. Estimated IUCN Red List status - EN.

Distribution. Southern China: southeastern Yunnan (Malipo and Pingbian counties), northern Vietnam: northwestern Ha Giang (Quan Ba district)? Fig. 3B.

Notes. The last assessment estimates this species as Endangered [B1ab(ii,iii,v)+2ab(ii,iii,v); C2a(i); D] (Rankou, Averyanov, 2014a). However, expected area of the species occupancy as $20 \mathrm{~km}^{2}$ looks certainly overestimated and in fact it is much smaller. Actually, years ago it was recorded from three locations only (Cribb, Chen, 1999; Chen, Liu, 2004; Chen, Cribb, 2005). Since the assessment in 2014, no information about any extant populations of this extremely rare plant became available. It is highly probably that the species is presently extinct, or stands on the verge of full extinction in the nature. Commercial collecting of the species for horticultural purposes, as well as for regional and 
international trade depletes its populations even in officially protected areas.

The species is one of the most sensitive elements of primary open limestone forests and scrub associated with a specific set of habitat conditions, such as rocky high elevations, nutrient availability, mossy steep slopes and permanent humidity. Such forests are critically endangered in the area and occupy presently miserable table-like summits of karstic remnant limestone hills or ridges surrounded typically by vertical cliffs. This unique kind of vegetation composed with many aboriginal species disappears very fast due to timber exploitation, forest fires, urbanization, soil erosion and climate drought connected with wide deforestation.

Botanical exploration in the species area can discover more extant population of this rare species. Their assessment and organization of effective protection can prevent coming extinction of this plant in nature.

Studied specimens. In fact, species is known solely by type specimens of $C$. lentiginosum, C. daweishanense and C. malipoense, as well as by few photographs made in the nature by local peoples and originated supposedly from the state ChinaVietnam border area hardly accessible for scientific exploration.

Acknowledgements. Field and laboratory studies were supported in part by The Mohamed bin Zayed Species Conservation Fund (Conservation assessment of endangered Lao-Vietnamese stenoendemic - Pinus cernua, 152511753) and by the Russian Foundation for Basic Research (Plant taxonomy, geography and biology in local floras of eastern Indochina, 15-04-00419 A).

\section{REFERENCES / ЛИTEPATУPA}

Averyanov L. $\boldsymbol{V}$. 1999. Genus Cypripedium (Orchidaceae) in the Russia. Turczaninowia 2, 2: 5-40 [In Russian]. (Аверьянов Л. В. Род Сурripedium (Orchidaceae) на территории России // Turczaninowia, 1999. Т. 2, вып. 2. С. 5-40).

Averyanov L. V. 2000. The genus Cypripedium (Orchidaceae) in Russia. Lindleyana 15, 4: 197-221.

Chen S. C., Cribb P. J. 2005. Cypripedium. In: Flora of China. Eds. Z. Y. Wu, P. H. Raven, D. Y. Hong. Science Press, Beijing \& Missouri Botanical Garden Press, St. Louis., 25: 22-33.

Chen S. C., Lang K. Y. 1986. Cypripedium subtropicum, a new species related to Selenipedilum. Acta Phytotax. Sin. 24, 4: 317-322.

Chen S. C., Liu Z. J. 2004. A new species and new variety of Cypripedium (Orchidaceae) from China. Acta Bot. Yunnan 26, 4: 382-384.

Cribb P. J. 1997. The Genus Cypripedium. Timber Press, Portland, 301 pp.

Cribb P., Chen S. C. 1999. A new species of Cypripedium from south-east Yunnan. Bull. Alpine Gard. Soc. 67, 2: $155-158$.

Eccarius W. 2009. Die Orchideengattung Cypripedium. Echinomedia, Buergel, 384 pp.

Jiang H., Liu E. 2009. The quest for an elusive slipper orchid Cypripedium subtropicum rediscovered. Orchid Digest. 73: 240-245.

Li J.-H., Liu Zh.-J., Salazar G. A., Bernhardt P., Perner H., Tomohisa Y., Jin X.-H., Chung Sh.-W., Luo Y.-B. 2011. Molecular phylogeny of Cypripedium (Orchidaceae: Cypripedioideae) inferred from multiple nuclear and chloroplast regions. Mol. Phylogenet. Evol. 61: 308-320.

Liu Z. J., Chen L. J. 2009. Cypripedium singchii, a new species of Orchidaceae from China. Journ. Fariylake Bot. Gard. 8, 2: 1-3.

Rankou H., Averyanov L. 2014a. Cypripedium lentiginosum. The IUCN Red List of Threatened Species 2014: e.T201846A2722359. URL: http://dx.doi.org/10.2305/IUCN.UK.2014-1.RLTS.T201846A2722359.en. (Assessed 28 January 2017).

Rankou H., Averyanov L. 2014b. Cypripedium subtropicum. The IUCN Red List of Threatened Species 2014: e.T201848A2722593. URL: http://dx.doi.org/10.2305/IUCN.UK.2014-1.RLTS.T201848A2722593.en. (Accessed 28 January 2017). 